\title{
Pengaruh etika kerja, motivasi kerja dan kompensasi finansial terhadap kinerja karyawan
}

\author{
Agung Budianto ${ }^{1}$, Yonathan Pongtuluran ${ }^{2}$, Syaharuddin $\mathbf{Y}^{3}$ \\ Fakultas Ekonomi dan Bisnis Universitas Mulawarman, Samarinda. \\ ${ }^{1}$ Email: agung.budianto@mhs.feb.unmul.ac.id \\ ${ }^{2}$ Email: yonathan.pongtuluran@feb.unmul.ac.id \\ ${ }^{3}$ Emai: syaharuddin.y@feb.unmul.ac.id
}

\begin{abstract}
Abstrak
Tujuan penelitian ini adalah untuk menguji pengaruh etika kerja, motivasi kerja dan kompensasi finansial terhadap kinerja. Metode yang digunakan purposive sampling dengan teknik non-probability sampling. Sampel dalam penelitian ini sebanyak 70 responden. Metode analisis data yang digunakan adalah Regresi Linier Berganda menggunakan SPSS versi 23. Hasil penelitian ini menunjukan bahwa: Etika Kerja berpengaruh signifikan terhadap kinerja dibuktikan dengan output dimana nilai thitung > ttabel. Motivasi Kerja berpengaruh signifikan terhadap kinerja dibuktikan dengan output dimana nilai thitung $>$ ttabel. Dan Kompensasi Finansial berpengaruh signifikan terhadap kinerja dibuktikan dengan output dimana nilai thitung>ttabel.

Kata Kunci: Etika kerja; motivasi kerja; kompensasi finansial

\section{The influence of work ethics, work motivation and financial compensation on employee performance}

Abstract

The purpose of this study was to determine the influence of work ethic, work motivation and financial compensation on performance. The method used is the purposive sampling with non-probability sampling techniques. The sample in this study were 70 respondents. Data analysis method in this study is Multiple Linier Regression using SPSS version 23. The result of this study show that: has a significant influence of work ethic on performance evidence by output where the value tarithmetic >ttable. Work motivation has a significant influence on performance evidence by output where the value tarithmetic > ttable. And Financial compensation on performance has a significant influence on performance evidence where the value tarithmetic >ttable.
\end{abstract}

Keywords: Work ethic; work motivation; financial compensation 


\section{PENDAHULUAN}

Karyawan merupakan kekayaan utama sebuah perusahaan, karena keikutsertaannya merupakan kunci dari berjalannya aktivitas sebuah perusahaan. Dalam setiap koorporasi yang sukses yang dipimpin oleh seorang wirausahawan yang visioner, pasti memiliki karyawan yang mumpuni, sehingga penting bagi perusahaan untuk dapat mengoptimalkan karyawan yang dimiliki sesuai dengan fungsinya agar dapat menjadi aset yang berkualitas dan unggul yang wujud nyatanya dapat dilihat melalui kinerja karyawan. Kinerja merupakan hasil kerja yang dicapai karyawan dalam waktu tertentu sesuai dengan tugas serta tanggung jawabnya. Kinerja harus selalu dievaluasi, hal ini guna mengidentifikasi keadaan hasil kerja karyawan pada jangka waktu tertentu, mengetahui hambatan serta rintangan yang akan dan telah dihadapi, serta untuk mengukur apakah kinerja karyawan sejauh ini sudah cukup efektif dan efisien dalam mendukung pencapaian tujuan perusahaan secara khusus untuk memaksimalkan laba perusahaan.

Faktor yang dapat mempengaruhi kinerja adalah etika kerja. Dalam membina kemampuan bekerja dan meningkatkan kinerja masing-masing karyawan, tidak terlepas dari etika kerja yang di yakini oleh individu individu tersebut. Etika kerja merupakan sikap, pandangan, kebiasaan, ciri-ciri atau sifat mengenai cara bekerja yang dimiliki seseorang, suatu golongan atau suatu bangsa.

Etika kerja yang tinggi tentunya rutinitas tidak akan membuat bosan, bahkan mampu meningkatkan prestasi kerjanya atau kinerja. Hal yang mendasari etika kerja tinggi di antaranya keinginan untuk menjunjung tinggi mutu pekerjaan, maka individu yang mempunyai etos kerja tinggi akan turut serta memberikan masukan-masukan ide di tempat bekerja.

Kompensasi juga sangat penting dan berpengaruh dalam meningkatkan kinerja karyawan. Kompensasi adalah segala sesuatu yang diterima para karyawan sebagai balas jasa atas kerja mereka dan kompensasi itu sendiri dapat dibagi menjadi dua yaitu kompensasi langsung dan kompensasi tidak langsung. Kompensasi langsung yaitu berupa gaji, upah, dan insentif. Sedangkan kompensasi tidak langsung berupa asuransi, tunjangan, cuti, penghargaan. Pemberian kompensasi ini dimaksudkan agar apapun yang menjadi kebutuhan karyawan dapat terpenuhi lalu diharapkan para karyawan dapat berkerja dengan baik dan merasa senang dengan semua tugas yang diembannya. Setelah karyawan merasa senang dengan pekerjaannya, para karyawan akan saling menghargai hak dan kewajiban sesama karyawan sehingga terciptalah suasana kerja yang kondusif. Pada akhirnya karyawan akan bersungguh-sungguh memberikan kemampuan terbaiknya dalam menjalankan tugas dan tanggung jawabnya.

Faktor lain yang mempengaruhi kinerja adalah motivasi. Motivasi merupakan hal yang sangat penting untuk diperhatikan oleh pihak manajemen bila mereka menginginkan setiap karyawan dapat memberikan kontribusi positif terhadap pencapaian tujuan perusahaan. Karena dengan motivasi, seorang karyawan akan memiliki semangat yang tinggi dalam melaksanakan tugas yang dibebankan kepadanya. Tanpa motivasi, seorang karyawan tidak dapat memenuhi tugasnya sesuai standar atau bahkan melampaui standar karena apa yang motivasinya dalam bekerja tidak terpenuhi. Mangkunegara (2009:20) mengemukakan perbedaan motif dan motivasi yaitu motif merupakan suatu dorongan kebutuhan dalam diri pegawai yang perlu dipenuhi agar pegawai tersebut dapat menyesuaikan diri terhadap lingkungannya, sedangkan motivasi adalah kondisi yang menggerakkan pegawai agar mampu mencapai tujuan dari motifnya.

\section{Kajian Pustaka}

\section{1) Etika Kerja}

Menurut Griffin \& Ebert dalam Gania (2007:58) etika merupakan keyakinan mengenai tindakan yang benar dan yang salah, atau tindakan yang baik dan yang buruk, yang mempengaruhi hal lainnya. Jadi, etika kerja dapat diartikan sebagai doktrin tentang kerja yang diyakini oleh seseorang atau sekelompok orang sebagai baik dan benar yang mewujud nyata secara khas dalam perilaku kerja mereka. 
2) Motivasi Kerja

Motivasi adalah suatu proses yang menghasilkan suatu intesitas, arah dan ketekunan inividual dalam usaha untuk mencapai satu tujuan. Sementara motivasi umum bersangkutan dengan upaya ke arah setiap tujuan (Robbins dalam Yunowo, 2011: 208).

3) Kompensasi Finansial

Menurut Mutiara Pangabean dalam Subekhi (2012:176) kompensasi adalah setiap bentuk penghargaan yang diberikan karyawan sebagai balas jasa atas kontribusi yang mereka berikan kepada organisasi.

4) Kinerja

Kinerja merupakan hasil kerja yang dicapai seseorang.Konsep kinerja merupakan singkatan dari kinetika energi kerja atau yang juga sering disebut dengan performance.

\section{METODE}

Penelitian ini menggunakan pendekatan kuantitatif yang merupakan metode penelitian yang digunakan untuk meneliti data yang bersifat statistik agar dapat menguji suatu hipotesis. Metode analisis data dalam penelitian ini menggunakan analisis regresi linier berganda. Populasi dalam penelitian ini adalah seluruh karyawan Ramayana yang berjumlah 115 karyawan.

Besarnya Sampel dalam penelitian ini sebanyak 70 responden dengan kriteria karyawan yang bekerja dibidang penjualan seperti SPG/SPB, Pramuniaga, Kasir. Metode pengumpulan data menggunakan teknik penelitian lapangan dengan mengumpulkan data-data yang diperlukan dengan menggunakan teknik kuesioner, yaitu dengan menggunakan daftar pernyataan yang akan diisi oleh responden dengan skala likert 1-5. Kuesioner yang disebar berupa daftar pertanyaan kepada responden mengenai Etika kerja, Motivasi Kerja, Kompensasi Finansial dan Kinerja.

\section{HASIL DAN PEMBAHASAN}

\section{Uji Validitas dan Reabilitas}

Hasil pengujian validitas kuesioner dari semua variabel independen dan dependen memiliki nilai koefisien korelasi lebih besar dari rtabel $>0,3$ sehingga semua penyataan dinyatakan valid. Uji Reabilitas dalam penelitan ini memiliki nilai cronbach's alpha lebih besar dari > 0,60 (Etika Kerja sebesar 0,784; Motivasi Kerja sebesar 0,812;

Kompensasi Finansial sebesar 0,835; kinerja sebesar 0,808) maka seluruh variabel dalam penelitian dinyataka reliable.

\section{Analisis Liner Berganda}

Berdasarkan tabel 3 diperoleh nilai koefisien korelasi (R) sebesar 0,880 atau sebesar 88\% yang menunjukkan terdapat hubungan yang "sangat kuat" antara variabel Etika Kerja, Motivasi Kerja dan Kompensasi Finansial terhadap Kinerja, karena semakin nilai R mendekati 1, maka semakin menunjukkan semakin kuatnya pengaruh variabel independen terhadap variabel dependen. Nilai koefisien determinasi (R2) diperoleh nilai sebesar 0,775 yang berarti etika kerja, motivasi kerja dan kompensasi finansial mampu menjelaskan kinerja karyawan sebesar 77,50\%, sedangkan sisanya 22,50\% di jelaskan oleh variabel lain yang tidak dimasukkan kedalam penelitian ini. Serta Nilai signifikansi F sebesar 0,000 <0,05 Nilai Fhitung $>$ Ftabel $(75,870>2,74)$ yang berarti bahwa secara bersama-sama (simultan) variabel Etika Kerja, Motivasi Kerja dan Kompensasi Finansial berpengaruh positif dan signifikan terhadap Kinerja Karyawan. 


\section{Analisis Uji Parsial (t)}

Uji parsial digunakan untuk menguji pengaruh masing-masing variabel independen yaitu Etika Kerja, Motivasi Kerja dan kompensasi finansial terhadap variabel dependen yaitu kinerja. Dari hasil pengolahan data, maka dapat dilihat hasil sebagai berikut:

\section{1) Pengaruh Etika Kerja terhadap Kinerja Karyawan}

Hasil pengujian pada penelitian ini menunjukkan bahwa Etika Kerja berpengaruh positif dan signifikan terhadap kinerja karyawan PT. Ramayana Lestari Sentosa, Tbk. Cabang Samarinda Square yang diukur dengan empat indikator dan dibuktikan dengan nilai output dari thitung > ttabel $(4,418>1,995)$ serta nilai signifikansi 0,000 lebih kecil dari $5 \%$ atau 0,05 yang menunjukkan variabel etika kerja berpengaruh positif dan signifikan terhadap kinerja karyawan. Hal ini menunjukkan bahwa semakin tinggi dan baik etika kerja karyawan pada sebuah perusahaan akan berpengaruh positif terhadap kinerja karyawan tersebut.

\section{2) Pengaruh Motivasi Kerja terhadap Kinerja Karyawan}

Hasil pengujian yang dilakukan dalam penelitian ini menunjukkan bahwa motivasi kerja berpengaruh positif dan signifikan terhadap kinerja karyawan PT. Ramayana Lestari Sentosa, Tbk. Cabang Samarinda Square yang diukur dengan tiga indikator dan dibuktikan dengan nilai output thitung > ttabel $(2,027>1,995)$ serta nilai signifikansi sebesar 0,047 lebih kecil dari 5\% atau 0,05 yang menunjukkan variabel Motivasi Kerja berpengaruh positif dan signifikan terhadap kinerja karyawan. Dimana dalam hal ini, berdasarkan indikator- indikator yang telah ditetapkan dalam penelitian, terbukti bahwa semakin tinggi Motivasi yang diberikan perusahaan kepada karyawan akan meningkatkan semangat dalam bekerja bagi karyawan untuk memajukan suatu perusahaan.

\section{3) Pengaruh Kompensasi Finansial terhadap Kinerja Karyawan}

Hasil pengujian yang dilakukan dalam penelitian ini menunjukkan bahwa kompensasi finansial berpengaruh positif dan signifikan terhadap kinerja karyawan PT. Ramayana Lestari Sentosa, Tbk. Cabang Samarinda Square yang diukur dengan tiga indikator dan dibuktikan dengan nilai output thitung > ttabel $(2,452>1,995)$ serta nilai signifikansi sebesar 0,017 lebih kecil dari $5 \%$ atau 0,05 yang menunjukkan variabel Kompensasi Finansial berpengaruh positif dan signifikan terhadap kinerja karyawan. Artinya apabila kompensasi meningkat karyawan akan merasa puas sehingga kinerja menjadi meningkat, berarti perfonmasi yang baik akan menjadi feedback bagi usaha pekerja pada tahap berikutnya.

\section{SIMPULAN}

Berikut kesimpulan yang dapat diambil dari penelitian ini:

a. Etika kerja berpengaruh positif dan signifikan terhadap kinerja karyawan PT. Ramayana Lestari Sentosa, Tbk. Cabang Samarinda Square, yang artinya semakin baik etika kerja dalam perusahaan, maka akan semakin baik pula kinerja karyawan yang akan dihasilkan.

b. Motivasi kerja berpengaruh positif dan signifikan terhadap kinerja karyawan PT. Ramayana Lestari Sentosa, Tbk. Cabang Samarinda Square, yang artinya semakin baik motivasi kerja yang diberikan oleh perusahaan, maka akan semakin baik pula kinerja yang akan dihasilkan karyawan untuk perusahaan.

c. Kompensasi Finansial berpengaruh positif dan signifikan terhadap kinerja karyawan PT. Ramayana Lestari Sentosa, Tbk. Cabang Samarinda Square, yang artinya semakin baik kompensasi finansial yang diberikan oleh perusahaan, maka akan semakin baik pula kinerja yang akan dihasilkan karyawan untuk perusahaan. 


\section{DAFTAR PUSTAKA}

Anwar, Prabu Mangkunegara. 2009. Manajemen Sumber daya manusia. PT. Remaja Rosdakarya, Bandung

Griffin, Ricky W., dan Ronald, J. Ebert. 2007. Bisnis. Alih Bahasa Gina Gania. Edisi Kedelapan. Erlangga, Jakarta

Robbins SP,. dan Judge. 2011. Perilaku organisasi. Alih Bahasa V. A Yunowo. Salemba Empat, Jakarta

Subekhi, Akhmad., Mohammad Jauhar. 2012. Pengantar Manajemen Sumber Daya Manusia. Prestasi Pustaka, Jakarta. 